\title{
Effect of tempe gembus on cholesterol profile in hyperlipidemic rats
}

\author{
Mohammad Sulchan, MG Isworo Rukmi
}

\begin{abstract}
Abstrak
Ateroskerosis dan penyakit jantung koroner telah menjadi masalah kesehatan utama di Indonesia. Tingginya kadar lipid darah merupakan faktor risiko yang dapat dikendalikan dengan pengaturan diet. Seperti halnya tempe kedele, tempe gembus-bahan pangan yang bergiz-diketahui mengandung zat-zat yang dapat mempengaruhi kadar lipid darah. Penelitian ini mengkaji pengaruh berbagai konsentrasi tempe gembus terhadap profil lipid tikus-hiperlipidemik. Perlakuan tempe gembus yang diberikan adalah 0\%, 4\%, 8\%, $12 \%(b / b)$. Hasil penelitian menunjukkan bahwa perlakuan tempe gembus $0 \%$ menurunkan kadar trigliserida, kolesterol total kolesterol HDL dan rasio HDL/LDL, serta menaikkan kadar kolesterol LDL. Perlakuan tempe gembus $4 \%$ meningkatkan kadar trigliserida, menurunkan kolesterol total, kolesterol-LDL dan HDL, serta menaikkan rasio HDL/LDL. Perlakuan tempe gembus 8\% meningkatkan kadar trigliserida, menurunkan kadar kolesterol total, kolesterol LDL dan HDL, dan menaikkan rasio HDl/LDL. Perlakuan tempe gembus $12 \%$ meningkatkan kadar trigliserida, menurunkan kadar kolesterol total, kolesterol LDL dan HDL, serta menaikkan rasio HDL/LDL. Akan tetapi, pengaruh tempe gembus yang bermakna hanyalah dalam menurunkan kolesterol total dan kolesterol LDL (perlakuan 8\% dan 12\%), namun juga menurunkan kadar kolesterol HDL (perlakuan 0 dan 12\%). Dengan demikian, rasio kolesterol HDL/LDL yang meningkat hanya terjadi pada perlakuan $8 \%$. (Med J Indones 2007; 16:205-11)
\end{abstract}

\begin{abstract}
Atherosclerosis and coronary heart disease has become a prominent health problem in Indonesia. High blood lipid level is considered to be among the risk factors, that can be controlled by dietary treatment. Like tempe kedele, tempe gembus, a nutritious food, is known to contain many substances that is able to influence blood lipid level. This study was conducted to investigate the effect of various concentrations of tempe gembus on blood lipid profile in hyperlipidemic rats. Tempe gembus were given in variations of 0\%, 4\%, 8\%, and $12 \%(w / w)$. The result of this study showed that $0 \%$ tempe gembus decreased triglyceride, total cholesterol, and HDL cholesterol level, and cholesterol HDL/LDL ratio, and increased LDL cholesterol level. Four percent tempe gembus increased triglyceride level, decreased total cholesterol, LDL and HDL cholesterol level, and increased HDL/LDL ratio; 8\% tempe gembus increased triglyceride level, decreased total cholesterol, LDL, and HDL cholesterol level, and increased HDL/LDL ratio; 12\% tempe gembus increased triglyceride level, decreased total cholesterol, LDL, and HDL cholesterol level, and increased HDL/LDL ratio. However, a significant effect of tempe gembus were only the decrease in total cholesterol, and LDL cholesterol (8\% and 12\% treatment), and increase in cholesterol HDL/LDL ratio only happend in $8 \%$ treatment. (Med J Indones 2007; 16:205-11)
\end{abstract}

Keywords: total cholesterol, LDL cholesterol, HDL cholesterol, triglyceride

In Indonesia, the prevalence of atherosclerosis and coronary heart disease (CHD) has increased. It is predicted that the prevalence will be in the first rank in contributing to mortality in the next decade. ${ }^{1}$ High blood lipid level is a risk factor in the development of atherosclerosis and CHD. People with CHD and those who have multiple risk factors for CHD are usually advised to make dietary and lifestyle changes to reduce their risk before considering drug therapy. ${ }^{1,2}$

Programme of Nutrition Biomedic, Medical Faculty, Diponegoro University, Semarang, Indonesia
The ATP III guidelines recommend an approach to risk reduction called therapeutic lifestyle changes (TLC), whose main features are a cholesterollowering diet, weight reduction, and regular physical activity. $^{2}$ A number of well-controlled studies have shown that diets low in saturated fat and cholesterol, and high in soy protein like soy tempe can reduce LDL cholesterol levels, especially when soy protein replaces foods that contain animal fats. ${ }^{3}$

There are more than thirty varieties of tempe. Although soy tempe is by far the most popular type, it is by no means the only one. One of the favorites in Indonesia is tempe gembus (in Japan: okara). It is 
made from soy pulp left over after the preparation of soy bean curd. Tempe originated hundreds of years ago in Central Java, and has long served as a source of low-cost protein in the diets of both rich and poor population. Tempe, including tempe gembus contains no cholesterol and makes a delicious and inexpensive replacement for main-course dishes high in cholesterol and saturated fats. ${ }^{4-6}$ Like the soy tempe, tempe gembus contains several substances i.e. fiber, polyunsaturated fatty acids, ergosterol and isoflavonoids, which are assumed to have influences on the level of blood lipids. ${ }^{5,6}$

Based on this background, the experiment was conducted to investigate and to compare the effect the various concentrations of tempe gembus on blood triglyceride and cholesterol level in hyperlipidemic rats.

\section{METHODS}

This was an experimental study, with randomized prepost test-control group design. It was performed from May 2003 to November 2004.

Twenty eight Sprague Dawley male rats, aged 10 weeks and weighing 230-260 grams, were obtained from Pusat Penelitian Obat dan Makanan Departemen Kesehatan. They were put in individual cages. Animal experiment was conducted in the Development Unit of Experimental Animal, Gajah Mada University. Tempe gembus flour was obtained from local home industry, using inoculum from LIPI, with $6 \%$ water content. Cholesterol crystal (USP Cholesterin) was the product of Merck no.3670. and the palm oil, Vetco, purchased from the local market was used to dissolve the crystal. Cholesterol profile was analyzed using reagent kit for cholesterol (10.017), HDL cholesterol (10.018), and triglyceride (10.164) from HumanBavaria GmBH.

There are three periods of experiments. The preparatory period was carried out for 7 days to acclimatize the rats to the experimental conditions, by ad libitum consumption of standard food AIN-93M, followed by pre-experimental period of 28 days, during which the rats were given cholesterol crystal dissolved in palm oil orally, to raise the blood lipid level. To get hyperlipidemic rats using this diet, a significant increase in blood lipid level was previously observed. ${ }^{7}$ In the experimental period, during 5 weeks, the rats were divided into four groups randomly, and each group was given purified diet based on AIN-93M plus $0 \%$ (namely G-0, control group), 4\% (G-1), $8 \%$ (G-2), and $12 \%$ (G-3) tempe gembus (w/w) respectively. Wastes of the experimental diet and the body weights of rats were measured daily. At the beginning and the end of experimental period, total cholesterol, LDL and HDL cholesterol, and triglyceride level were determined. ${ }^{8}$ For the 4 groups, the mean of total cholesterol, LDL and HDL cholesterol, and triglyceride at the beginning and the end were compared using the paired t-test. The difference between the beginning and the end of all data in all groups were calculated, and difference between the beginning and the end data in the four groups (G0, G1, G2, G3) were compared by one way analysis of variance (Anova) followed by least significant difference test for inter group comparison using SPSS for Windows version 11.0 with the limit of significance of 0.05 .

\section{RESULTS}

\section{Preparatory period}

During this period the rats were acclimatized to the new environment. At the end of the period data collected represented the baseline data. The average of body weight at the beginning of this period was $341.57 \mathrm{~g} \pm 18.15 \mathrm{~g}$ and increased to $349.77 \pm 20.71$ $\mathrm{g}$ at the end of the period.

The result of the analysis of nutritional value of tempe gembus (dry weight per $100 \mathrm{~g}$ edible portion) consisted of energy (77.70 kkal), protein (4.07 g), lipid (0.23 g), total carbohydrate $(14.25 \mathrm{~g})$, fiber $(4.69 \mathrm{~g})$, ash $(0.84 \mathrm{~g})$, calcium $(159.98 \mathrm{mg}$ ), phosphorous $(59.69 \mathrm{mg})$, iron $(0.48 \mathrm{mg})$, and water $(6 \%)$.

\section{Pre-experimental period}

Amino acids and fatty acids composition of tempe gembus used in this study are a presented in table 1 and table 2 .

During pre-experimental period, the rats were successfully brought into hyperlipidemic condition by daily oral administration of a solution of $0.2 \%$ cholesterol in palm oil. The level of serum total cholesterol, LDL and HDL cholesterol at the start and end of preexperimental period were presented in table 3 . 
Table 1. Amino acid composition of tempe gembus (per $100 \mathrm{~g}$ edible portion)

\begin{tabular}{lcc}
\hline \multicolumn{1}{c}{ Amino Acids } & $\begin{array}{c}\text { Tempe Gembus } \\
\text { (wet weight) }\end{array}$ & $\begin{array}{c}\text { Tempe Gembus } \\
\text { (dry weight) }\end{array}$ \\
\hline Aspartatic acid & 0.22 & 0.27 \\
Glutamic acid & 0.29 & 0.35 \\
Serine & 0.06 & 0.07 \\
Histidine & 0.05 & 0.60 \\
Glysin & 0.13 & 0.16 \\
Threonine & 0.08 & 0.95 \\
Arginine & 0.09 & 0.11 \\
Alanine & 0.13 & 0.16 \\
Tyrosine & 0.06 & 0.72 \\
Methionin & 0.01 & 0.12 \\
Valine & 0.14 & 0.17 \\
Phenylalanine & 0.08 & 0.09 \\
Isoleucine & 0.10 & 0.12 \\
Leucine & 0.14 & 0.17 \\
Lysine & 0.12 & 0.14 \\
Cystein & 0.01 & 0.00 \\
\hline
\end{tabular}

Table 2. Fatty acid composition of tempe gembus (per $100 \mathrm{~g}$ edible portion)

\begin{tabular}{lc}
\hline \multicolumn{1}{c}{ Fatty acids } & $\begin{array}{c}\text { Tempe Gembus } \\
\text { (dry weight) }\end{array}$ \\
\hline Caprylic acid (8: 0) & 0.26 \\
Capric acid (10: 0) & 0.39 \\
Lauric acid (12: 0) & 3.46 \\
Myristic acid (14: 0) & 1.71 \\
Palmitic acid (14: 0) & 8.23 \\
Stearic acid (18:0) & 3.42 \\
Oleic acid (18: 1$)$ & 16.72 \\
Linoleic acid (18: 2) & 21.51 \\
Linolenic acid (18: 3) & 1.82 \\
\hline
\end{tabular}

Table 3. Serum lipid profile of rats at the start and the end of the pre-experimental period

\begin{tabular}{cccc}
\hline Lipid Profile & Start & En d & $P$ \\
\hline $\begin{array}{c}\text { Total cholesterol } \\
(\mathrm{mg} / \mathrm{dl})\end{array}$ & $95.37 \pm 8.21$ & $142.20 \pm 8.55$ & 0.00 \\
$\begin{array}{c}\mathrm{LDL} \text { cholesterol } \\
(\mathrm{mg} / \mathrm{dl})\end{array}$ & $3.43 \pm 0.49$ & $19.07 \pm 4.03$ & 0.00 \\
$\begin{array}{c}\mathrm{HDL} \text { cholesterol } \\
(\mathrm{mg} / \mathrm{dl})\end{array}$ & $70.80 \pm 3.47$ & $85.00 \pm 3.37$ & 0.00 \\
$\begin{array}{c}\text { Triglyceride } \\
(\mathrm{mg} / \mathrm{dl})\end{array}$ & $108.81 \pm 8.04$ & $142.20 \pm 8.55$ & 0.00 \\
\hline
\end{tabular}

\section{Experimental period}

\section{Body weight}

There was no apparent change in the body weight of the rats, indicating that the dietary treatment did not have any adverse effect. Furthermore, there was no significant difference in body weight between experimental groups compared to control group $(P>0.05)$.

\section{Triglyceride}

Serum triglyceride concentration was decreased in G0 treatment, whereas in G-1, G-2 and G-3 treatments the concentrations were increased. However, the changes in triglyceride concentrations were not significant statistically (Table 4). More over, analysis of variance showed that there were no difference in the effect of dietary treatments on the increase/decrease in triglyceride concentration (Table 4).

Table 4. Serum triglyceride levels before and after treatment and their differences

\begin{tabular}{cccccc}
\hline \multirow{2}{*}{ Group } & Before $(\mathrm{mg} / \mathrm{dl})$ & \multirow{2}{*}{ After $(\mathrm{mg} / \mathrm{dl})$} & \multicolumn{2}{c}{ Difference } & \multirow{2}{*}{$P$} \\
\cline { 5 - 5 } & & $\mathrm{mg} / \mathrm{dl}$ & $\%$ & \\
\hline $\mathrm{G}-0$ & $140.77 \pm 6.66$ & $139.79 \pm 2.63$ & -0.98 & -0.7 & 0.761 \\
$\mathrm{G}-1$ & $143.64 \pm 10.96$ & $148.75 \pm 5.73$ & 5.11 & 3.6 & 0.162 \\
$\mathrm{G}-2$ & $141.88 \pm 8.34$ & $145.88 \pm 2.72$ & 4.08 & 2.9 & 0.118 \\
$\mathrm{G}-3$ & $143.90 \pm 6.75$ & $148.43 \pm 2.14$ & 4.53 & 3.1 & 0.169 \\
\hline
\end{tabular}

One - way Anova: $\mathrm{F}=0.961$ and $P=0.427$

\section{Total cholesterol}

The addition of tempe gembus in the diet has resulted in a decrease in total cholesterol level. The decrease seemed to be greater in accordance with the increase of tempe gembus concentration in the diet. However, the decrease in total cholesterol level also occured in G-0 group that did not get tempe gembus in the diet, though the decrease was smaller in comparison with G-1, G-2 and G-3 groups. The difference in total cholesterol level before and after treatment in G-2 and G-3 groups were significant statistically $(P<0.05)$, whereas in G-0 and G-1 were not. However, analysis of variance showed that there were no difference in the increase/decrease of total cholesterol level across treatments (Table 6). 
Table 5. Serum total cholesterol levels before and after treatment and their differences

\begin{tabular}{llllll}
\hline \multirow{2}{*}{ Group } & \multirow{2}{*}{ Before $(\mathrm{mg} / \mathrm{dl})$} & \multirow{2}{*}{ After $(\mathrm{mg} / \mathrm{dl})$} & \multicolumn{2}{c}{ Difference } & \multirow{2}{*}{$P$} \\
& & $\mathrm{mg} / \mathrm{dl}$ & $\%$ & \\
\hline G-0 & $132.75 \pm 5.12$ & $130.47 \pm 4.19$ & -2.28 & 1.7 & 0.075 \\
G-1 & $131.75 \pm 8.60$ & $129.38 \pm 0.93$ & -2.37 & 1.8 & 0.474 \\
G-2 & $131.13 \pm 5.98$ & $125.48 \pm 1.44$ & -5.65 & 4.3 & $0.040^{*}$ \\
G-3 & $134.62 \pm 6.99$ & $125.51 \pm 2.46$ & -9.10 & 6.8 & $0.027^{*}$ \\
\hline
\end{tabular}

One way Anova: $\mathrm{F}=1.6627$ and $P=0.2016$

\section{HDL cholesterol}

Investigation on HDL cholesterol level showed a decrease in all groups including G-0 (Table 6). The largest decrease in HDL cholesterol level occurred in G-0 group, whereas the smallest decrease was in G-1 group, and the decreases were subsequently increased in accordance with the increase in tempe gembus concentration in the diet. Analysis of variance showed that there were differences between the 4 groups in the decrease of HDL cholesterol $(P<0.05)$. In further test using least significant difference, the significant difference was between G-0 and both G-1 \& G-2 groups, whereas there was no significant difference between G-0 and G-3 group. T test comparing HDL cholesterol level before and after treatment in G-0 group showed, in fact, a very significant difference statistically $(P<0.01)$, followed by $\mathrm{G}-3$ group $(P<0.05)$, whereas in G-1 and G-2 groups the differences were not significant statistically (Table 6).

Table 6. Serum HDL cholesterol levels before and after treatment and their differences

\begin{tabular}{cccccc}
\hline \multirow{2}{*}{ Group } & \multirow{2}{*}{ Before $(\mathrm{mg} / \mathrm{dl})$} & \multirow{2}{*}{ After $(\mathrm{mg} / \mathrm{dl})$} & \multicolumn{2}{c}{ Difference } & \multirow{2}{*}{$P$} \\
\cline { 4 - 5 } & & $\mathrm{mg} / \mathrm{dl}$ & $\%$ & \\
\hline $\mathrm{G}-0$ & $84.26 \pm 2.44$ & $77.76 \pm 1.07$ & $-6.52^{\mathrm{a}}$ & 7.7 & $0.001^{*}$ \\
$\mathrm{G}-1$ & $84.67 \pm 2.88$ & $83.60 \pm 0.46$ & $-1.13^{\mathrm{b}}$ & 1.3 & 0.372 \\
$\mathrm{G}-2$ & $83.66 \pm 2.54$ & $82.29 \pm 1.16$ & $-1.46^{\mathrm{b}}$ & 1.7 & 0.116 \\
$\mathrm{G}-3$ & $87.22 \pm 4.49$ & $81.82 \pm 1.07$ & $-5.39^{\mathrm{a}}$ & 6.2 & $0.029^{*}$ \\
\hline
\end{tabular}

- One - way Anova: F= 4.4678 and $P=0.0123$

- $a, b$ value within one category with different letter were significantly different from each other, $P<0.05$ (ANOVA, post-hoc multiple comparisons test of least significant difference)

\section{LDL cholesterol}

In our study, tempe gembus in diet could lower LDL cholesterol levels, whereas in G-0 diet that did not contain tempe gembus, the LDL cholesterol level was increased. The decrease in LDL cholesterol level seemed to be bigger with the increase in tempe gembus concentration in the diet. Analysis of variance indicated that statistically there were differences between treatments $(P<0.05)$. In further test using least significant difference it was found that there were significant difference statistically between G-0 group and G-1, G-2 and G-3 groups $(P<0.05)$. More over, $\mathrm{t}$ test in G-2 and G-3 group showed that LDL cholesterol level before and after treatment statistically differed significantly $(P<0.05)$ (Table 7$)$.

Table 7. Serum LDL cholesterol levels before and after treatment and their differences

\begin{tabular}{|c|c|c|c|c|c|}
\hline \multirow{2}{*}{ Group } & \multirow{2}{*}{ Before (mg/dl) } & \multirow{2}{*}{ After (mg/dl) } & \multicolumn{2}{|c|}{ Difference } & \\
\hline & & & $\mathrm{mg} / \mathrm{dl}$ & $\%$ & \\
\hline & & & $4.02^{b}$ & 18. & 0.153 \\
\hline & & & $-2.23^{\mathrm{a}}$ & 12.7 & 0.405 \\
\hline G - & & & $-4.97^{\mathrm{a}}$ & 23.1 & $0.010^{*}$ \\
\hline$G-3$ & $18.67 \pm 3.13$ & $14.00 \pm 1.38$ & $-4.62^{a}$ & 24.8 & $0.013^{*}$ \\
\hline
\end{tabular}

- One - way Anova: $\mathrm{F}=5.257$ and $P=0.006$

- $a, b$ value within one category with different letter were significantly different from each other, $P<0.05$ (ANOVA, post-hoc multiple comparisons test of least significant difference)

\section{Serum HDL/LDL cholesterol ratio}

It has been reported that a decrease in serum HDLcholesterol level slightly, combined with a higher decrease in LDL cholesterol level, resulted in the increase of HDL/LDL cholesterol ratio, as was found in our study presented in table 8 . The largest increase in HDL/LDL cholesterol ratio occurred in G-2 group, whereas the smallest increase occurred in G-1 group. Analysis of variance showed that were differences between groups in term of the increase/decrease in HDL/LDL cholesterol ratio $(P<0.05)$. Further least significant difference test showed significant differences between G-0 group and G-1, G-2, and G-3 groups $(P<0.05)$. The result of $t$ test on HDL/LDL cholesterol ratio indicated that only in G-2 group was the ratio between before and after treatment significantly different statistically $(P<0.05)$. 
Tabel 8. Serum HDL/LDL Cholesterol ratios before and after treatment and their differences

\begin{tabular}{cccccc}
\hline \multirow{2}{*}{ Group } & \multirow{2}{*}{$\begin{array}{c}\text { Before } \\
(\mathrm{mg} / \mathrm{dl})\end{array}$} & $\begin{array}{c}\text { After } \\
(\mathrm{mg} / \mathrm{dl})\end{array}$ & \multicolumn{2}{c}{ Difference } & \multirow{2}{*}{$P$} \\
\hline $\mathrm{G}-0$ & $4.09 \pm 1.06$ & $3.26 \pm 0.21$ & $-0.83^{\mathrm{b}}$ & 20.1 & 0.313 \\
$\mathrm{G}-1$ & $4.61 \pm 0.43$ & $5.21 \pm 0.36$ & $0.60^{\mathrm{a}}$ & 13.0 & 0.182 \\
$\mathrm{G}-2$ & $4.41 \pm 1.25$ & $5.87 \pm 0.65$ & $1.46^{\mathrm{a}}$ & 33.1 & $0.039^{*}$ \\
$\mathrm{G}-3$ & $4.68 \pm 1.43$ & $5.84 \pm 0.77$ & $1.16^{\mathrm{a}}$ & 24.8 & 0.298 \\
\hline
\end{tabular}

- One - way Anova: $\mathrm{F}=4.998$ and $P=0.008$

- $a, b$ value within one category with different letter were significantly different from each other, $P<0.05$ (ANOVA, post-hoc multiple comparisons test of least significant difference)

\section{DISCUSSION}

In experimental period, tempe gembus with various concentrations could change the profile of serum lipid, by decreasing total cholesterol, and LDL and HDL cholesterol, but increasing triglyceride slightly though not all the changes were statistically significant. The increase in triglyceride was similar in the three experimental groups. These findings are in agreement with those of previous investigators, using tempe kedele in the treatment. ${ }^{7}$ When the experimental groups $(\mathrm{G}-1$, G-2, G-3) were compared to the control group (G-0), it seems that tempe gembus $8 \%$ and $12 \%$ gave the best result in decreasing LDL cholesterol and increasing HDL/LDL cholesterol ratio significantly. However, there were also significant decreases in HDL cholesterol levels, though some were minimal, except in G-0 and G-3.

The significant decrease in the level of LDL cholesterol and significant increase in HDL/LDL cholesterol ratio may be due to the addition of tempe gembus to the diet. This is probably due to the nutritional value of tempe gembus, especially the various fatty acids, amino acids, fiber, isoflavone, vitamin $\mathrm{E}$ and calsium. ${ }^{7-10}$

Triglyceride level in blood may vary; it depends on food consumption, both in amount and type of fat contained in the food. Diet with saturated fat will cause more increase in postprandial lipid level in human, in comparison with diet that contains polyunsaturated fatty acid n-3 or n-6. ${ }^{11}$ In our study, statistical test did not indicate that there were significant difference in the change in triglyceride level between the 4 groups. However, the tendency of increase in triglyceride level in G-1, G-2 and G-3 groups might be due to the oil content in the diet, as we used a mixture of soybean and coconut oil (1:1) containing saturated fatty acid (caprilate, laurate, miristate, palmitate and stearate) and unsaturated fatty acid (oleate, linoleate, linolenate) in almost equal proportion.
Cholesterol level in blood serum is influenced by cholesterol intake from food (exogenous) and cholesterol synthesis in the body (endogenous). ${ }^{10-11}$ Endogenous cholesterol synthesis will decrease when the need for cholesterol has been supplied sufficiently by exogenous cholesterol. This regulation occurs through restriction in biosynthetic pathway in the liver because of the reduced production of the enzyme 3-hydroxy-3 methylglutaryl co-enzyme A (HMGCoA) reductase whose function is to limit the rate in cholesterol synthesis pathway. ${ }^{10-12}$ In our study, total cholesterol levels were decreased in all groups, including the control group (G-0). The largest decrease occurred in G-3 (6.8\%), followed by G-2 group (4.3\%). However, there was no significant difference in the decrease in cholesterol level between the 4 groups.

In G-0 and G-1 group, the decrease in total cholesterol level was very low, and this might be due to the absence or low content of tempe gembus in comparison with G-2 and G-3 groups. Diet containing tempe gembus tended to decrease blood cholesterol level due to (among others) the fiber and unsaturated fatty acid content, whose amount increased in accordance with the increase of tempe gembus concentration in the diet. ${ }^{9-11}$ In this study, unsaturated fatty acid content in the diet could come from oil sources (linoleic and oleic acid), as well as from tempe gembus itself (oleic, linoleic and linolenic acid).

It has been reported that total cholesterol in serum will decrease with the increase of polyunsaturated fatty acid content, whereas monounsaturated fatty acid (oleic acid) has neutral influence on total cholesterol level. ${ }^{9-11,13}$ However, saturated fatty acids (SFAs) of different chain lengths have variable influences on total and LDL cholesterols, i.e. palmitic (16:0), lauric (12:0), and myristic (14:0) acids raise both serum total and LDL cholesterols, whereas stearic acid (18:0) has no effect on them. ${ }^{10,12}$ Replacing saturated fats with monounsaturated or polyunsaturated fats can lower LDL cholesterol level. Polyunsaturated fats have a slightly greater effect but can also promote a slight reduction in HDL cholesterol. ${ }^{10}$ When SFAs are replaced with poly unsaturated fatty acid (PUFA) in a low-fat diet, LDL, and HDL cholesterol levels will be lowered such that and thus HDL/LDL cholesterol ratio will be elevated. Overall, eliminating SFAs is twice as effective in lowering serum cholesterol levels as in increasing PUFA. Gotto as quoted by BrataArbai suggested that PUFA can decrease cholesterol concentration by stimulating cholesterol excretion and cholesterol oxydation to become bile. In addition, 
PUFA increases LDL receptor regulation so that LDL catabolism process is accelerated and plasma cholesterol will be distributed to the tissues. ${ }^{9,10,13}$

According to several studies, the decrease in serum cholesterol level was also influenced by fiber concentration in diet. ${ }^{14,15}$ Tempe gembus, which is made of the waste of soybean in tofu making process, is rich in fiber (4.69\%), and contains a three fold greater level in fiber compared with tempe kedele $(1.40 \mathrm{gr} \%)$. Fiber content will increase in accordance with the increase of tempe gembus concentration in the diet. In our study, the difference from treatment to treatment was about $19 \mathrm{gr} / \mathrm{kg}$ edible portion. The fiber of soybean is a carbohydtrate that is difficult to digest. The mechanism in lowering blood cholesterol level by food rich in viscous fibers is due to their binding to bile acids and thereby increasing their excretion. Consequently, the liver should use its cholesterol to make new bile acids. In addition, the bacterial by products of fiber fermentation in the colon also inhibit cholesterol synthesis in the liver. It is important to recognize that fermentable oligosaccharides and dietary fibers are converted by intestinal bacteria to short chain fatty acids (SCFAs), ${ }^{11,15}$ that lower blood cholesterol.

The results of studies mainly on rats and rabbits showed that the mechanism of tempe protein in reducing cholesterol could happen through several ways: 1) digested tempe protein transported to the liver decreases negative feedback on the transformation of cholesterol into bile acid, and biosynthesis of cholesterol increases in accordance with the increase in LDL receptor, that promotes the loss of cholesterol in blood through LDL receptor, and finally decreases cholesterol level in blood; 2) protein residue that is not digested will bind bile acid and cholesterol in the lumen of intestine, that will result in the decrease in absorption of cholesterol and bile acid. ${ }^{16,17}$ The mechanism above occurs through the increase in HMGCoA reductase and the activity of apo B and apo E receptor and the decrease in the activity of cholesterol $7 \alpha$-hydroxylase. ${ }^{16,18,19}$

In the diet that did not contain tempe gembus (G-0), the decrease in HDL cholesterol might occur as a result of the decrease in total cholesterol level that occurred in this group. Several researchers supposed that the decrease in total cholesterol might be followed by a slight decrease or unchanged HDL cholesterol level. Several researchers demonstrated that the composition of amino acid in protein had a role in determining the influence of the involved protein on serum cholesterol. The amount of unsaturated fatty acid content in tempe gembus, mainly linoleic and linolenic acid, played a role in decreasing HDL cholesterol concentration. Polyunsaturated fatty acid causes a decrease in HDL cholesterol through suppression of synthesis through a decrease in apo A-I concentration, that is the pre-substance for HDL formation. Saturated fatty acid results in chylomicron of larger size, and the larger surface has greater ability to bring apo A-I that is the pre-substance for HDL. ${ }^{20,21}$

In mice, amino acid cysteine decreases cholesterol level by increasing glutathion production, whereas methionine increases cholesterol. ${ }^{18,21}$ Analysis on amino acid content showed that tempe gembus did not contain cysteine, whereas methionine was found in concentration of $11.9 \mathrm{mg} / 100 \mathrm{gr}$. This is in extreme contrast with soybean tempe that contains cysteine $(70 \mathrm{mg} / 100 \mathrm{gr})$ and methionine $(168 \mathrm{mg} / 100 \mathrm{gr})$.

The mechanism of the increase of LDL cholesterol in G- 0 could be due to diet composition that did not contain vegetable protein sufficiently, and saturated fatty acid content that was lower in comparison with other diet composition, because $\mathrm{G}-0$ did not contain tempe gembus at all. A lot of studies have been performed to try to understand the mechanism at molecular level, about how saturated fat can affect plasma LDL concentration. The decrease of LDL in plasma can happen as a result of an increase in LDL receptor activity, that is possibly caused by protein and amino acid content in diet. In addition, PUFAs increase the regulation of LDL receptor, so that LDL catabolism process is accelerated and plasma cholesterol is distributed to the tissues. Polyunsaturated fatty acid increases bile acid and cholesterol secretion in the gall bladder, by increasing the regulation of LDL receptor in the liver. Another possible cause concerning a decrease of cholesterol might be due to the content of calcium. Tempe gembus contains $159.98 \mu \mathrm{g} \%$ calcium. In our study, it could produce a slight decrease in LDL cholesterol. Part of its rationale includes the possibility that calcium forms insoluble soaps (calcium-bile acid complex) with the availability of fatty acids, and therefore increasing fecal bile acid excretion. ${ }^{18,20,22}$

Concerning significant difference in cholesterol level between before and after treatment in G-2 and G-3, there was a possibility that phytochemicals present in the diet might play a role, as has been shown in several studies. ${ }^{21,22}$ Phytosterols are plant sterols that inhibit absorption of both endogenous and exogenous cholesterol and lower serum total and LDL cholesterol 
level. In addition, flavonoids, and isoflavonoids are present in soy food like tempe gembus. ${ }^{22}$ The composition of isoflavones in Okara (Japan) is similar to tempe gembus. The isoflavones concentration in tempe gembus (wet food) are daidzein $(33.1 \mu \mathrm{g} / \mathrm{g})$ and genistein $(57.1 \mu \mathrm{g} / \mathrm{g})$, that are slightly higher compared with the concentration in raw green soy been. Another study revealed that reductions of total plasma cholesterol, LDL cholesterol and triglyceride level were demonstrated after eating isoflavones from soya; and patients with higher initial cholesterol levels demonstrated larger reduction in LDL cholesterol level. The hypocholesterolaemic effect of soya may be due to the increase in the number of LDL receptors. ${ }^{18,19,22}$

In this study, the change in serum lipid fraction caused by tempe gembus in diet was small and only showed significant differerence that were not consistent.

However, we recommended tempe gembus, that is a popular (especially in Central Java) nutritious food, to be introduced and popularized, not only for its relatively inexpensive price, but also for its value as nutritious food, and its possible role in affecting serium lipid level. Further studies are needed to investigate the effects of tempe gembus prepared by a variety of cooking methods on serum lipid level, and the roles of the various nutrients present in tempe gembus in human health.

In conclusion, $8 \%$ tempe gembus in diet showed the best result in decreasing total and LDL cholesterol level and increasing HDL/LDL cholesterol ratio significantly. However, triglyceride and HDL cholesterol tended to increase, though it was not significant.

\section{REFERENCES}

1. Wijaya A. Risk factor of cardiovascular disease a new perspective. Forum Diagnosticum. 1998; 2 : 1-11.

2. Tande DL, Hotchkiss L, Cotugna N. The associations between blood lipids and the food guide pytramid: findings from the third national health and nutrition examination survey. Prev Med. 2004; 38: 452-7.

3. Zhang X, Shu XO, Gao Y T, Yang G, Li Q, Li H, et al. Soy food consumption is associated with lower risk of coronary heart disease risk reduction in Chinese women. J Nutr. 2003; 133 : 2874-8.

4. Adnan M, Sudarmadji S. Contribution of tempe for the economic and health of Indonesian. Proceedings of International Tempe Symposium. Reinventing the Hidden Miracle of Tempe. Bali. 1997 July 13-15. Denpasar: Udayana Press; p.11-21.

5. Sumi H, Yatagai C. Fermented soybean component and disease prevention. In: Sugano M, editor. Soy in Health and disease prevention. $1^{\text {st }}$ ed. New York: CRC Press; 2006. p. 263-6.

6. Ornish D, Scherwitz LW, Billings JH. Intensive lifestyle changes for reversal of coronary heart disease. JAMA. 1998; 280: 2001-7.

7. Jenkins DJ, Kendall CW, Marchie A. The effect of combining plant sterols, soy protein, viscous fibers, and almonds in treating hypercholesterolemia. Metabolism. 2003; 52: 1478-83.

8. Ard JD, Franklin FA. Cardiovascular disease. In: Heimburger DC, Ard JD, editors. Handbook of clinical nutrition. 4 th ed. Philadelphia: Mosby; 2006. p.422-31.

9. Brata Arbai AM. Tempe and hypercholesterolemia. In: Sapuan and Soetrisno N, editors. Bouquet of Indonesian tempe. Jakarta: Indonesian Tempe Foundation; 1998. p.101-45.

10. Krummel DA. Medical nutrition therapy in cardiovascular disease. In: Mahan LK, Stump SE, editors. Krause's food, nutrition $\&$ diet therapy. $11^{\text {th }}$ eds. Philadelphia : Elsevier Press; 2004. p.878-81.

11. Rosell MS, Appleby PN, Spencer EA, Key TJ. Soy intake and blood cholesterol concentrations: a cross-sectional study of 1033 pre- and postmenopausal women in the Oxford arm of the European prospective investigation into cancer and nutrition. Am J Nutr. 2004; 80: 1391-6.

12. Clarkson TB. Soy phytoestrogens and cardiovascular disease. J Nutr. 2002; 132: 566S-9S.

13. Djousse L, Arnett DK, Coon H, Province MA, Moore LL, Ellison RC. Fruit and vegetable consumption and LDL cholesterol: the National Heart, Lung, and Blood Institute family heart study. Am J Clin Nutr. 2004; 79: 213-7.

14. Nagata C, Tatatsuka N, Kurisu Y, Shimizu H. Decreased serum total cholesterol concentration is associated with high intake of soy products in Japanese men and women. $\mathrm{J}$ Nutr. 1998; 128: 209-13.

15. Sembor SM. Fibers from soy pulp and tempe gembus. The effect on sort chain fatty acid and lipid profiles in rats serum. [thesis]. Jogjakarta: Post graduate program University of Gadjah Mada; 1998.

16. Sirtori CR, Gianazza E, Mansoni C, Lovati MR, Murphy PA. Role of isoflavones in the cholesterol reduction by soy proteins in the clinic. Am J Nutr. 1997; 65: 166-7.

17. Kritchevsky D. Dietary fiber in health and disease: an overview. Asia Pacific J Clin Nutr. 1999; 8 (suppl): S1-2.

18. Idris CA, Sundram SK. Effect of dietary cholesterol, trans and saturated fatty acids on serum lipoprotein in non human Asia Pasific. J Clin Nutr. 2002; II (suppl) : s 408-15.

19. Weggemans RM, Trautwein EA. Relation between soyassociated isoflavones and LDL and HDL cholesterol concentrations in humans: A meta-analysis. Eur J Clin Nutr. 2003; 57: 940-6.

20. Zhuo. XG, Melby MK, Watanabe S. Soy isoflavone intake lowers serum LDL cholesterol: a meta-analysis of 8 randomised control trials in humans. J Nutr. 2004; 134: 2395-400.

21. Mensink RP, Zock PL, Kester ADM, Katan MB. Effect of dietary fatty acids and carbohydrates on the ratio of serum total HDL cholesterol and on serum lipids and apolipoproteins: a meta-analysis of 60 controlled trials. Am J Clin Nutr. 2003; 77: 1146-55.

22. Gardner CD, Newell KA, Cherin R, Haskell WL. The effect of soy protein with or without isoflavones relative to milk protein on plasma lipids in hypercholesterolemic postmenopausal women. Am J Clin Nutr. 2001; 73: 728-35. 
